\title{
The French domestic "sanitary pass" did not solve Covid- 19 vaccination inequities in France
}

Débarre Florence ${ }^{1}$, Lecoeur Emmanuel ${ }^{2}$, Guimier Lucie ${ }^{3}$, Jauffret-Roustide Marie ${ }^{4,5,6}$, Jannot Anne-Sophie $7,8,9$

Affiliations

1. Institute of Ecology and Environmental Sciences of Paris (IEES-Paris, UMR 7618), CNRS, Sorbonne Université, UPEC, IRD, INRAE, 75252 Paris, France

2. Clinical research unit, Hôpital Européen Georges Pompidou, APHP, Paris, France

3. French Institute of Geopolitics, Paris, France

4. Centre d'Étude des Mouvements Sociaux (Inserm U1276/CNRS UMR8044/EHESS), Paris, France.

5. British Columbia Center For Substance Use (BCCSU), Vancouver, Canada.

6. Bady Center on Law and Social Policy, Buffalo, NY, USA.

7. Medical Informatics, biostatistics and public health unit, Hôpital Européen Georges Pompidou, APHP, Paris, France

8. Université de Paris, Paris, France

9. HeKA, Centre de Recherche des Cordeliers, Inserm, INRIA, Paris, France Corresponding author: Anne-Sophie Jannot, Hôpital Européen Georges Pompidou, 20 rue Leblanc, 75015 Paris. annesophie.jannot@aphp.fr

Keywords: vaccination, covid-19, data mining, socio-economic factors, health inequities.

\section{Acknowledgements}

We thank the producers of public datasets, in particular David Levy at INSEE and and Antoine Rachas at Assurance Maladie.

\section{Funding}

EL received funding to match socio-economic data with medical data from AP-HP Centre Université de Paris.

\section{Contributions}

ASJ designed the study with inputs from all authors. EL extracted socio-economic data at district scale and computed indicators. ASJ, EL and FD had full access to aggregated data used for this study and take responsibility for the integrity of the data. EL did the analyses and takes responsibility for the accuracy of the data analysis. FD drafted the paper with the help of ASJ, MR. All authors critically revised the manuscript for important intellectual content and gave final approval for the version to be published.

Conflict of interest statement

No conflict of interest to disclose

\section{Data sources}

- INSEE: https://www.insee.fr/fr/statistiques/5359146\#consulter

- Assurance Maladie: https://datavaccin-covid.ameli.fr/explore/dataset/donneesdevaccination-par-epci/https://datavaccin-covid.ameli.fr/explore/dataset/donnees-devaccination-parcommune/information/ 
medRxiv preprint doi: https://doi.org/10.1101/2022.01.03.22268676; this version posted January 5, 2022. The copyright holder for this preprint (which was not certified by peer review) is the author/funder, who has granted medRxiv a license to display the preprint in perpetuity.

It is made available under a CC-BY-ND 4.0 International license .

\section{Abstract}

The French sanitary pass led to an increase in vaccination rates in France, but local heterogeneities in vaccination rates remain. To identify potential determinants of these heterogeneities and how the French sanitary pass influenced them, we used a data-driven approach on exhaustive nationwide data, gathering 181 socio-economic and geographic factors. Our analysis reveals that, both before and after the introduction of the French sanitary pass, factors with the largest impact are related to poverty, with the most deprived areas having greater than 10 times the odds of being among the districts with lower vaccination rates.

\section{Introduction}

The rapid development of effective COVID-19 vaccines brought the hope of a rapid return to normalcy, but heterogeneous vaccination rates, both among countries because of inequitable distributions of doses [Usher21] and within countries [Caspi21, Murthy21], jeopardize epidemic control.

Hesitancy and hostility toward vaccination have been comparatively high in France in recent decades [Ward19], a trend confirmed with the COVID-19 pandemic [Lazarus21, Spire21], although acceptance of the COVID-19 vaccine gradually grew during 2021 [SantePubliqueFrance21].

Attitudes toward vaccination are known to be influenced by social and territorial inequalities. Surveys conducted in 2020 in France showed that respondents with lower education [Schwarzinger21, Spire21], lower income levels or less trust in authorities [Spire21] were more likely to be hostile to COVID-19 vaccines. Whether differential intentions translated into effective differences in vaccination, as described in other countries [Caspi21, Murthy21], remained to be shown in France.

To speed up vaccination, President Macron announced on 12 July 2021 the implementation of a domestic "sanitary pass" (le passe sanitaire), which came fully into force on 9 August 2021. It was required in most cultural venues, for both indoor and outdoor dining and in health structures. This announcement led to an unprecedented demand for vaccination, which was celebrated internationally. Vaccination rates climbed from $54 \%$ of the whole population by 12 July 2021 to $69 \%$ on 4 September 2021. Because it targeted pay-for social activities, however, the "sanitary pass" was feared to have a limited impact on vaccination inequities.

This study aims to obtain further insights into the association between social inequities, vaccination and sanitary pass implementation in France using nationwide data.

\section{Methods}

The French state health insurance service (Assurance Maladie) provides public datasets of exhaustive weekly first-dose vaccination data at the district scale nationally and at the suburban scale for the Paris, Lyon, and Marseille metropolitan areas. Our data included 1552 
medRxiv preprint doi: https://doi.org/10.1101/2022.01.03.22268676; this version posted January 5, 2022. The copyright holder for this preprint (which was not certified by peer review) is the author/funder, who has granted medRxiv a license to display the preprint in It is made available under a CC-BY-ND 4.0 International license.

districts in mainland France $(63,601,670$ individuals; median district size 22,705 inhabitants; interquartile range $6,282--39,128)$. We associated these data with 176 socioeconomic and 5 geographic indicators at the same geographic scales from public datasets.

We considered the association between being a district in the lowest quartile of the firstdose vaccination rate and being above the median value of each indicator. We computed odds ratios and their $95 \%$ confidence intervals at three time points: week 27 (just before the sanitary pass announcement), week 31 (when the sanitary pass came fully into force), and week 35 (end of data collection). For the two indicators achieving the highest odds ratios, we computed vaccination levels for each indicator quartile on the same dates. Analyses were done using $\mathrm{R}$ ( $\mathrm{v}$ 4.0.3).

\section{Results}

The two indicators most associated with local vaccination rates (figure 1 ) were the income rate coming from unemployment benefits (w27: OR=12.6 [8.7; 18.9]; w31: OR=13.3 [9.1; 20.0]; W35: OR=11.9 [8.2; 17.6]; the brackets correspond to $95 \% \mathrm{Cl}$ ) and the proportion of overcrowded households (w27: OR=11.6 [8,3; 16.4], w31: OR=12.0 [8.6; 17.1], w35: OR=15.7 [11.0; 23.0]).

The difference in vaccination rates (in percentage points) between the first and fourth quartiles of the two indicators remained similar across weeks (figure $\mathrm{S}_{1}$ ): unemployment w27: $\Delta \mathrm{Q}_{1-4}=7.6[6.6 ; 8.7], \mathrm{w}_{31}: \Delta \mathrm{Q}_{1-4}=8.0[7.0 ; 9.0], \mathrm{w}_{35}: \Delta \mathrm{Q}_{1-4}=7.9[6.9 ; 8.9]$, and overcrowding w27: $\Delta \mathrm{Q}_{1-4}=6.9[5.7 ; 8.1]$, w31: $\Delta \mathrm{Q}_{1-4}=7.6[6.6 ; 8.8], \mathrm{w}_{35}: \Delta \mathrm{Q}_{1-4}=8.2[7.2 ; 9.1]$.

\section{Discussion}

Our results based on exhaustive national datasets indicate that the most deprived areas have greater than 10 times the odds of being among the districts with lower vaccination rates. Lower vaccination rates in France are still associated with poverty, meaning that the sanitary pass did not resolve vaccine inequities. Specifically, living in a district with a large fraction of overcrowded housing or in which unemployment benefits represent a large share of the local income is a strong determinant of a lower COVID-19 vaccination rate in France.

Our study confirms the strong impact of social inequalities on COVID-19. The most deprived areas have already been shown to have been disproportionately infected and hospitalized during the pandemic [Jannot21, Bajos21]. We show that poorer districts are also the least vaccinated and, hence, the most still at risk, despite the widely celebrated domestic sanitary pass. There is an urgent need to define new vaccination policies that truly address social inequities. 
medRxiv preprint doi: https://doi.org/10.1101/2022.01.03.22268676; this version posted January 5, 2022. The copyright holder for this preprint (which was not certified by peer review) is the author/funder, who has granted medRxiv a license to display the preprint in It is made available under a CC-BY-ND 4.0 International license.

\section{References}

[1] Bajos, Nathalie, Florence Jusot, Ariane Pailhé, Alexis Spire, Claude Martin, Laurence Meyer, Nathalie Lydié, et al. 'When Lockdown Policies Amplify Social Inequalities in COVID19 Infections: Evidence from a Cross-Sectional Population-Based Survey in France'. BMC Public Health 21, no. 1 (December 2021): 705. https://doi.org/10.1186/s12889-021-10521-5.

[2] Caspi, Gil, Avshalom Dayan, Yael Eshal, Sigal Liverant-Taub, Gilad Twig, Uri Shalit, Yair Lewis, Avi Shina, and Oren Caspi. 'Socioeconomic Disparities and COVID-19 Vaccination Acceptance: A Nationwide Ecologic Study'. Clinical Microbiology and Infection, June 2021, S1198743X21002779. https://doi.org/10.1016/j.cmi.2021.05.030.

[3] Jannot, Anne-Sophie, Hector Countouris, Alexis Van Straaten, Anita Burgun, Sandrine Katsahian, and Bastien Rance. 'Low-Income Neighbourhood Was a Key Determinant of Severe COVID-19 Incidence during the First Wave of the Epidemic in Paris'. Journal of Epidemiology and Community Health, 30 June 2021, jech-2020-216068.

https://doi.org/10.1136/jech-2020-216068.

[4] Lazarus, Jeffrey V., Scott C. Ratzan, Adam Palayew, Lawrence O. Gostin, Heidi J. Larson, Kenneth Rabin, Spencer Kimball, and Ayman El-Mohandes. 'A Global Survey of Potential Acceptance of a COVID-19 Vaccine'. Nature Medicine 27, no. 2 (February 2021): 225-28. https://doi.org/10.1038/s41591-020-1124-9.

[5] Murthy, Bhavini Patel, Natalie Sterrett, Daniel Weller, Elizabeth Zell, Laura Reynolds, Robin L. Toblin, Neil Murthy, et al. 'Disparities in COVID-19 Vaccination Coverage Between Urban and Rural Counties - United States, December 14, 2020-April 10, 2021'. MMWR. Morbidity and Mortality Weekly Report 70, no. 20 (21 May 2021): 759-64. https://doi.org/10.15585/mmwr.mm7020e3.

[6] Santé Publique France. 'CoviPrev : Une Enquête Pour Suivre l'évolution Des Comportements et de La Santé Mentale Pendant l'épidémie de COVID-19', 2 November 2021. https://www.santepubliquefrance.fr/etudes-et-enquetes/coviprev-une-enquete-poursuivre-levolution-des-comportements-et-de-la-sante-mentale-pendant-I-epidemie-decovid-19\#block-325952.

[7] Schwarzinger, Michaël, Verity Watson, Pierre Arwidson, François Alla, and Stéphane Luchini. 'COVID-19 Vaccine Hesitancy in a Representative Working-Age Population in France: A Survey Experiment Based on Vaccine Characteristics'. The Lancet Public Health 6, no. 4 (April 2021): e210-21. https://doi.org/10.1016/S2468-2667(21)00012-8.

[8] Spire, Alexis, Nathalie Bajos, and Léna Silberzan. 'Social Inequalities in Hostility toward Vaccination against Covid-19'. Preprint. Public and Global Health, 10 June 2021. https://doi.org/10.1101/2021.06.07.21258461.

[9] Usher, Ann Danaiya. 'A Beautiful Idea: How COVAX Has Fallen Short'. The Lancet 397, no. 10292 (June 2021): 2322-25. https://doi.org/10.1016/S0140-6736(21)01367-2. 
medRxiv preprint doi: https://doi.org/10.1101/2022.01.03.22268676; this version posted January 5, 2022. The copyright holder for this preprint (which was not certified by peer review) is the author/funder, who has granted medRxiv a license to display the preprint in It is made available under a CC-BY-ND 4.0 International license.

[10] Ward, Jeremy K., Patrick Peretti-Watel, Aurélie Bocquier, Valérie Seror, and Pierre Verger. 'Vaccine Hesitancy and Coercion: All Eyes on France'. Nature Immunology 20, no. 10 (October 2019): 1257-59.

Figures 
igure 1

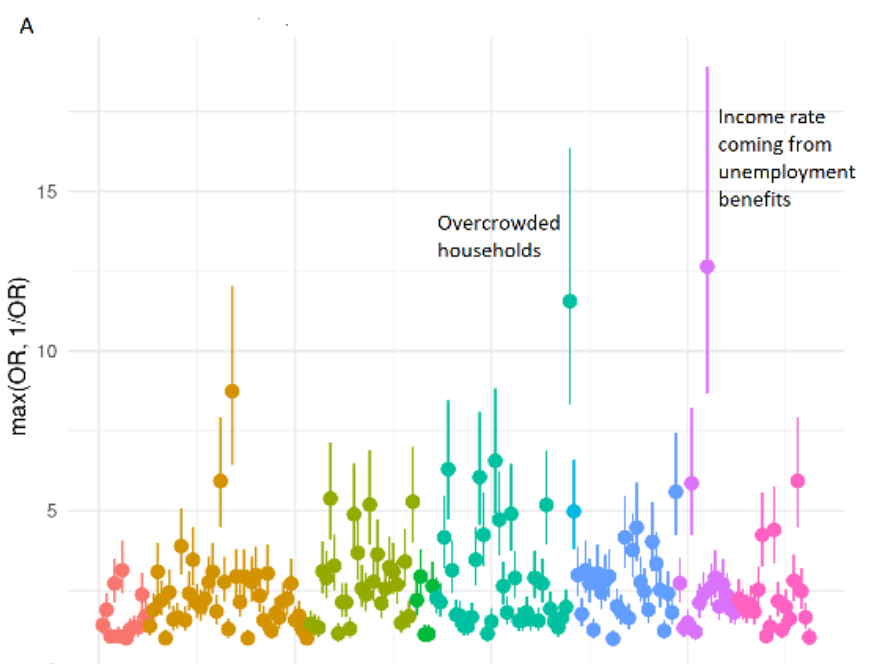

$0 \frac{1}{0}$

50

100
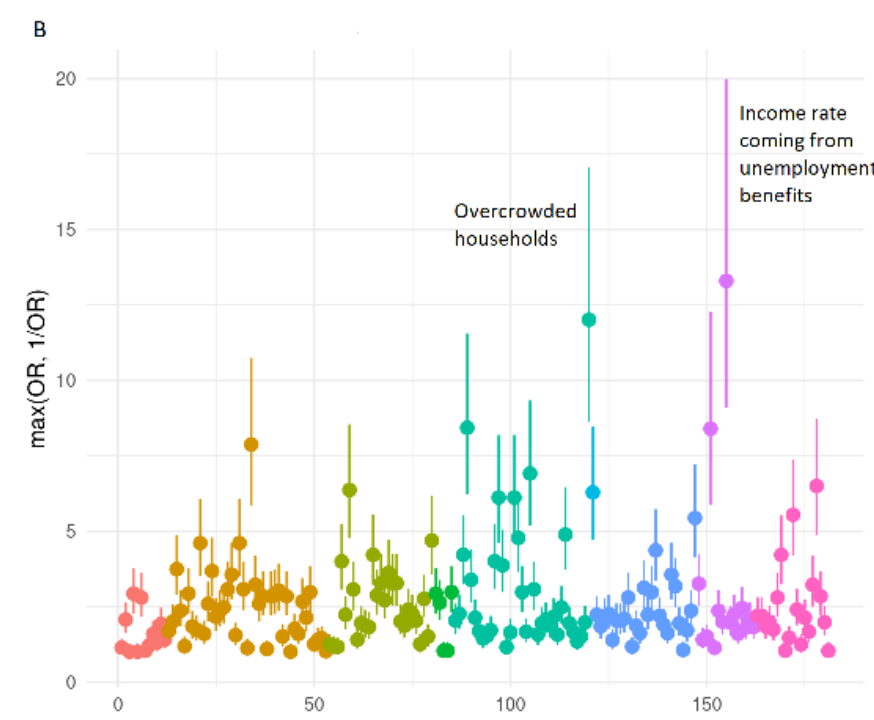

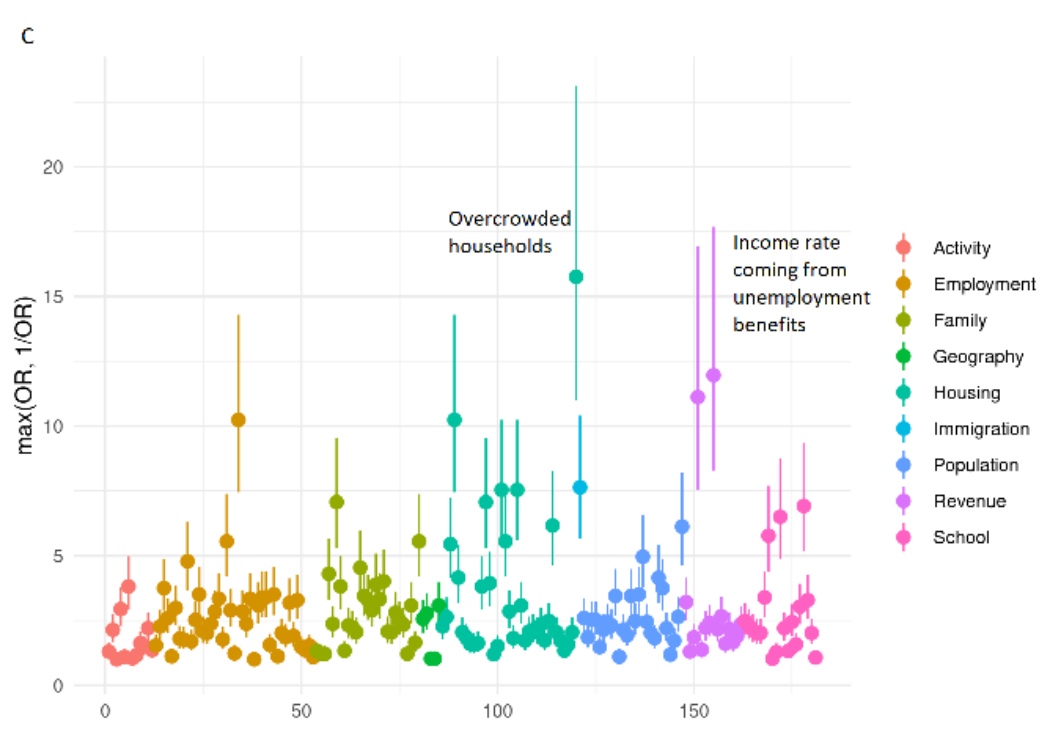

igure 1: Odds ratio (OR) and their $95 \%$ confidence intervals for the association between vaccination rate and each of the 181 selected indicators at week 27 (panel A), 31 (panel B) and 35 (panel C) 
medRxiv preprint doi: https://doi.org/10.1101/2022.01.03.22268676; this version posted January 5, 2022. The copyright holder for this preprint (which was not certified by peer review) is the author/funder, who has granted medRxiv a license to display the preprint in perpetuity.

It is made available under a CC-BY-ND 4.0 International license.

Figure 2

Week 追 27 官 31 官 35

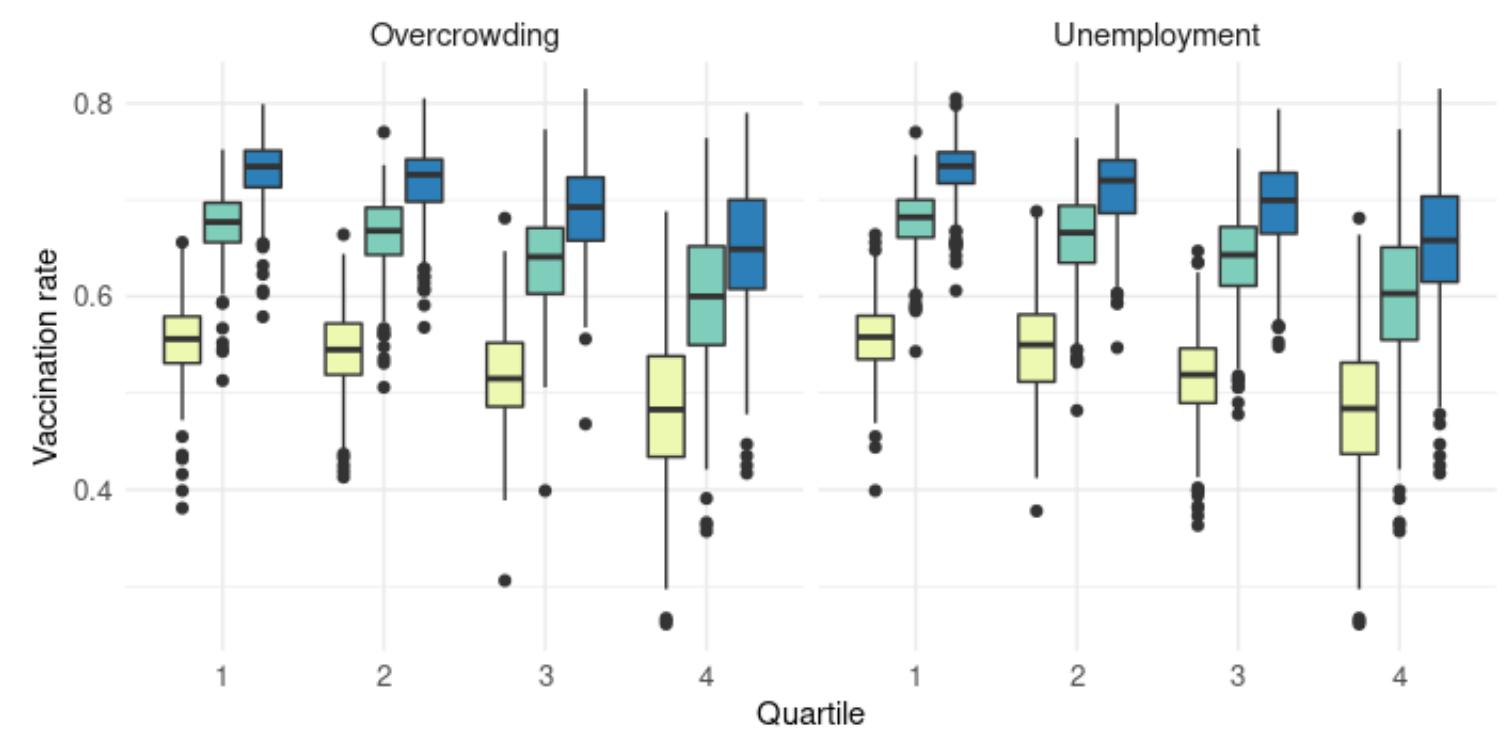

Figure 2: Local vaccination rates depending on the quartile of the two main indicators

(Overcrowding rate, left and Unemployment rate, right) and over time (weeks 27, 31, 35, with increasingly darker shading) 


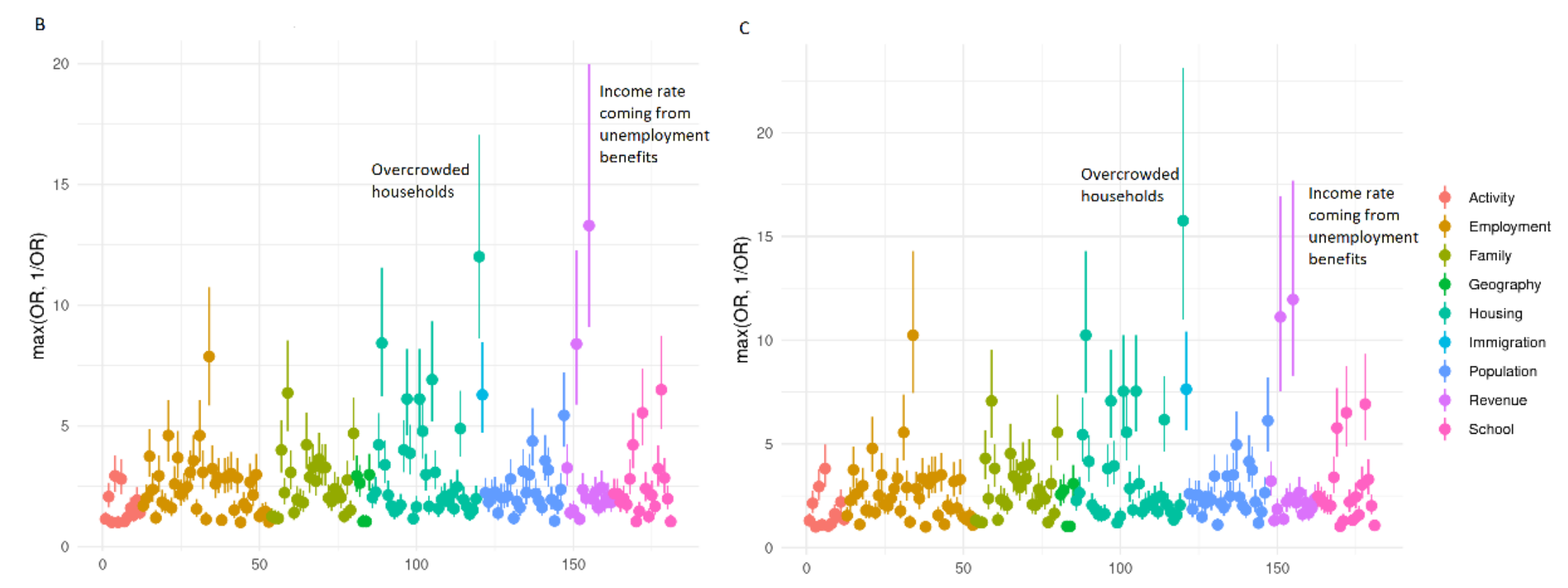


